\title{
Review of Literature on Teaching English Vocabularies Through Games to Young Language Learners
}

\author{
Amirhossein Naderiheshi \\ Department of Education, Monash University, Melbourne, Australia
}

\begin{abstract}
In the last two decades, learning English has become a popular activity in Iran (Sadeghi \& Richards, 2015). There has been a remarkable increase in the number of private language schools in the country. In Iran, interest in English has risen due to the status of the language as a lingua franca and its necessity for technical, scientific, and economic developments. Meanwhile, vocabulary is deemed as one of the most crucial aspects of learning a language. Currently, vocabularies are taught through traditional methods; therefore, young learners lose their interest over time. This paper aims to substantiate that games are profoundly effective in teaching vocabularies and affect young learners' motivation and engagement with the language. This paper presents a review of literature on teaching English vocabularies through games to young English language learners in Iran. It discusses the practical instructions of games and how games could be taught more effectively. It describes the suitability and implication of games and how they should be selected and implemented by teachers. Three games are introduced for teaching vocabularies and followed by a discussion on the inherent challenges of teaching vocabularies through games.
\end{abstract}

Index Terms - vocabulary, game, young learners, teaching English, challenges

\section{INTRODUCTION}

English is the lingua franca due to its pervasiveness among people for communication. Different sectors such as business, academia and multiple industries benefit from English to expand their fields (Naraghizadeh \& Barimani, 2013). The significance of English as an international language and people's interest in learning it has been explored in the literature (Crystal, 2003). Similar to many other countries, a surge in learning English is not an exception in the Middle East and Iran in particular.

Iranians learn English in public and private language schools as official foreign language of the country. However, many students graduating from public secondary schools cannot hold a basic conversation in English unless they take part in private English classes (Dorshomal, Gorjian, \& Pazhakh, 2013). Numerous Iranian students enrol in private language schools as they are the key players in effective English language education (Haghighi \& Norton, 2016; Moharami, 2020). Unlike public school education which focuses on grammar and the structure of the language, private schools provide a comprehensive view and address all the required skills a language learner needs (Maleki, Ghasemi, \& Moharami, 2015).

Many believe that syntax and grammar is the skeleton of the language. However, there is a consensus in the literature that vocabulary is "the vital organs and flesh" of the language (Hammer, 1991, p. 153). Learning vocabularies in a new language is an important domain as it ties together all four macro-skills (i.e., speaking, reading, writing, and listening) (Nguyen \& Khuat, 2003).

Vocabulary has been interpreted as words and phrases explaining things about a concept (Blachowicz \& Fisher, 2006). I believe vocabulary is the meaning and soul of a language. Linguists argue that vocabulary is an indispensable part of a language regardless if it is the L1 or L2 (Decarrico, 2001). Furthermore, linguists accept that teaching vocabularies should be the first step in new language education as it paves the path for good communication (Coady \& Huckin, 1997). In addition, language is learned in 'chunks', and it is these 'chunks' that form a coherent whole.

Occasionally, learning vocabularies can be frustrating for young learners (Ersoz, 2000). This opinion lies in our understanding of communication; when a student does not have a wide vocabulary range, it agitates the addressee and makes them terminate further communication (Wallace, 1982).

Due to the importance of vocabularies in a new language, traditional teaching methods are replaced with modern methodologies (Thornbury, 2006). Therefore, teachers use games to decrease the difficulties that younger learners face acquiring the L2. Gaining vocabulary competency is a time-consuming process (Stahl, 2005). Currently, new teachers are inclined to employ games in teaching vocabularies more than before (Halliwell 1992).

Although games have a positive impact, teachers occasionally overlook the inherent challenges and limitations of using games in teaching vocabulary. Teachers mainly employ games as a tool to prepare the class for the reception of new educational content or fill in the extra time after teaching (Khosravi, Moharami, \& Karimkhanlouei, 2014). Usually, at the very beginning of class, teachers use games as an ice breaker or at the end when there is no other task at hand. 
Many teachers are not familiar with the application and usage of games in language teaching and ignore their effectiveness. Teachers do not take games seriously and overlook the significance they have in language education. Rixon (1991) suggests that games can be implemented at any stage of a lesson, if they are appropriate and intertwine with what students are learning. Lee (1979) holds the opinion that games need to be at the centre of the teaching and learning cycle, not the peripheral. Richard-Amato (1988) mentions a similar idea as he contends that games are amusing and teachers should not disregard their pedagogical value.

\section{LITERATURE REVIEW}

Teaching vocabulary has been neglected for many years and is often not taken seriously (Carter, 1998). However, it is gaining momentum as an innovative strategy to engage learners; replacing the traditional grammar-based approach. While this methodology is not valued in traditional settings, most notably, the Middle East and parts of Asia, it is taking root in the private sector and progressive institutions.

Vocabulary is regarded as the key factor linking all skills required in communication (Huyen \& Nga, 2003). It is crucial for people who are learning a new language to improve their lexical repertoire. Learners with a large lexical resource understand different layers of meaning. This knowledge can be transferred to more specific tasks; tasks that engage learners with the target language. Krashen highlights the 'input hypothesis' where language is acquired in meaningful interactions. Games that are structured in such a way, assist learners in linking 'chunks' of language (i.e., vocabulary) to real-life situations.

According to Gairns and Redman (1986), three techniques utilised in teaching vocabulary include,

1. Visual aids: this helps students to associate what they learn in a meaningful way. This technique is considered useful for vocabulary retention. Students taught with visual aids learn the language faster (Uberman, 1998);

2. Verbal techniques: this means using synonyms, illustrative situations and opposites.

3. Dictionaries: students learn the meanings of words and model their language on the samples given.

There are different dictionaries with multiple outcomes, such as bilingual, monolingual, pictorial, and thesauri. Allen believes that dictionaries are "passports to independence", with students gaining autonomy in their learning (1983, p.57)

However, despite various educational methods, most Iranian young language learners forget new words and they do not know how or when to use them. This issue is due to several factors including inappropriate memorisation, inadequate practice and students' lack of interest or passion in learning the language (Rohani \& Pourgharib, 2013).

Learners of English encounter many new words as they develop their target language. Therefore, they need to adopt different strategies to practice what they learn. Good examples of this include participating in guessing and descriptive tasks or making conversation (Huyen \& Nga 2003). Along with students, teachers should implement various teaching methods to accommodate vocabulary learning for students as well.

It is believed that games pave the way for both students and teachers to have productive educational sessions. In other words, employing games in the class not only increase teachers' efficacy but also keep young language learners active or engaged in the class. Hung, Yang, Hwang, Chu, and Wang (2018) summarised eight games including immersive games, tutorial games, exergames, simulation games, adventure games, music games, board games, alternate reality games, immersive games and tutorial games are the most occurring ones.

Three games are very popular in the Iranian context and will be the focus of this study which includes;

- Back to the board,

- Bingo,

- Pictionary

The audience of these games are young language learners, and I have explored them further down. From author one's experience, he adds that these games are frequently employed in language schools in Iran. 'Back to the board' easily entertains young learners in the Iranian educational context. Efendi's (2013) study showed 'Back to the Board' improves students' vocabulary learning and achievement. The results of another study also showed that the vocabulary game 'Bingo' increases Iranian English language students' motivation in learning vocabulary (Al-Masri \& Najar, 2014). I have witnessed that 'Pictionary' had a profound effect on students' learning and it is highly regarded among Iranian teachers.

\section{YOUNG LEARNERS}

Young learners are aged between five to twelve years old, studying in primary school (Ersoz, 2007). According to Slattery and Willis (2001), young learners are characterised by several attributes, namely curiosity, imagination, and playfulness. In general, they learn by listening, watching, modelling, and practising. Teachers must consider the fact that their level is not a sign of maturity. Philips (1993) mentions numerous factors affecting the maturity of children including their gender, culture, environment, and parents. It is interesting to note that young learners cannot recognise the imaginary world from the real world (Ghasemi \& Moharami, 2014). Therefore, the situation is difficult for the teachers to understand young learners' perceptions to get along with the students.

According to Vygotsky (1962), children build up their knowledge by socialising and interacting. In other words, they need to participate in practical experiences to learn effectively (Donaldson, 1978; Hughes, 1986; Daneshfar \& 
Moharami, 2018). Young learners cannot concentrate for a long time however they have very high energy, so it is the best strategy to engage them in physical activities or games that include physical activities.

Phillips (1993) contends young learners are reserved and hold concerns toward learning a new language. Therefore, he stresses that teachers should benefit from games and improvise creativity to make educational activities less boring and simplified. The pleasure of games strengthens language learning and its depth. Language and accompanied entertainment complement each other. The combination of language and entertaining activities make learning meaningful and relevant. Children learn about their surroundings much easier through games, with the development of language skills a by-product of this activity.

\section{The Definition of A GAME}

The use of learning games has dramatically increased in educational contexts, leading to the emergence of gamebased learning as a recognised field. According to Klopfer, Osterweil, and Salen, (2009), a learning game is defined as a playful activity that consists of rules and regulations for the pursuit of quantifiable outcomes and incorporates educational objectives. Rogers, Miller and Hennigan (1981) also mentioned that games have specific goals and regulations. Games are fixed activities with a clear start and end and have a winner at the very end (Rixon, 1991).

Games and plays have been differentiated within the literature. Games are rule-based whereas plays are open-ended and without a defined purpose. Games are not used for mere playing as they have specific functions that can help the teachers and students (Piskozub, 1995). Games can be categorised into physical activities and computerised games. This study focuses on physical games as this is more evident and significant in teaching young language learners.

As Piskozub (1995) mentions, the interaction of the classroom and the organisation of work is one of the functions of the games. The rules and regulations of a game shape students' concentration on the content of the lesson. Piskozub (1995) believes that games are motivational. In other words, games make students more interested and engaged in the lesson. Moreover, games also have a didactic function. The fun and entertaining nature of games help students to develop their knowledge of vocabulary and grammar much better (Piskozub, 1995). It is also interesting to note that games draw students' attention and that they are less likely to become distracted. Games involving physical movement keep students alert and cautious; in other words, learners do not become bored quickly and the alleviating of their mood fortifies and consolidates what they learn.

Knowing different types of games allows teachers to adopt innovative strategies that engage younger learners. Each game has its advantages and disadvantages, with some more suited to beginners, and others to those who already have basic lexis. In addition, students who have developed their L1 can use their language base to acquire and familiarise themselves with the L2. Teachers need to recognise this, staging different games for students at different levels of their learning.

Why should teachers use games? Firstly, games provide a chance for learners to be active, dominant and strengthen their skills to compete, in collaboration with, other members of the class (Ersoz, 2000; Orlick, 2006). Secondly, games make classes entertaining and more importantly, they create an atmosphere and situation that is ready for better communication before, during, and after the game (Wright, Betteridge, \& Buckby, 2005). A decrease in young learners' anxiety is another important effect of playing games (Richard-Amato, 1988), especially students who are shy and need to connect with their peers (Uberman, 1998). Furthermore, games can cover all the core macro-skills, including speaking, writing, listening, and reading (Soyoof \& Jokar, 2014).

\section{Teaching Vocabulary Through Games to Young English Language Learners}

The heart of a language is vocabulary; without an adequate lexical resource, students are unable to communicate effectively (Cárdenas, 2004). Halliwell (1992) points out that children are naturally creative and that teachers need to pave the way by establishing a comfortable learning atmosphere. Educational games meet this demand: they are a valuable platform for language learning and foster the development of natural communication (Donmus, 2010).

Vocabulary is mostly taught separately and out of context in language schools in Iran, receiving extensive criticism (Al Neyadi, 2007). Studies have shown that traditional teaching methods are out-of-date, especially methodologies such as 'grammar translation' and the 'audiolingual' approach. Riahipour and Saba (2012) argue that old methods like memorising a long list of words, gap-fill exercises, and translating are tedious, and students become demotivated. Finally, they highlight that memorising long lists of words, without the fabric of the language, is meaningless and ineffective.

Aghlara and Tamjid (2011) suggest students using games with a vocabulary-led focus have the lead in comparison with students who use traditional methods. Aslanabadi and Rasouli (2013) explored the impact of games on Iranian English language learners' vocabulary development in nursery schools. The findings showed that not only games added fun and energy to the cohort but also helped them to build up their self-confidence.

Games are indeed crucial because they add diversion and act as an icebreaker. Teachers with a good repertoire of games take their learners further (Rixon, 1991). Nonetheless, teachers must be cautious in selecting the most suitable games for their students as some are not as conducive to language acquisition as others (Uberman, 1998). In Teacher Training Courses (TTC) teacher trainers are encouraging novices to use games to teach vocabulary. Games are 
becoming popular in teaching and learning foreign languages and scholars are conducting more research to find out their effects on young learners' achievements.

Vernon (2009) argues that games are effective in teaching vocabulary as they draw students' attention. This allows the application of analytical skills nurtured with meaningful content. They speak, engage, and think about their answers. They use the language and do not merely repeat it. Dolati and Mikaili (2011) also investigated the impact of games on the retention of vocabulary. They found that games can be used in education and can motivate inactive and quiet students to participate in whole-class activities.

Games make learning easier, relaxing, and motivational for young learners. Through games, students learn the language in a meaningful way and via authentic experiences (Lee, 1979). Scholars and linguists are unanimous about the motivational nature of games (Bakhsh, 2016; Chen, 2005; Ersoz, 2000; Al-Masri \& Najar, 2014). Moreover, games instigate positive competition among young learners (Derakhshan \& Khatir, 2015). Games act as a stimulator for learning, as they push learners towards interaction and engagement; with a motivation to succeed, students inadvertently develop the language skills required to do this, with vocabulary at centre stage (Allen, 1983). Games decrease stress, and as a result, students stay focused and learn better (Ajibade \& Ndububa, 2008; Chen, 2005; Al- Masri \& Najar, 2014). Games not only enable language acquisition, but the vocabulary learned is usually framed within the cultural dynamic in which they come from. Many surveys have confirmed that games have a profound effect on learning a foreign language (Chen, 2005).

\section{Practical InSTRUCTIONS USING GAMES}

Teachers should follow a two-step process when targeting the acquisition of vocabulary. Step one is grouping. This means teachers should allocate seating arrangements so that students sit close to each other and their peers. Such an arrangement promotes student talk-time and meaningful interaction, that is, the application of the language both before, during and post-game activity. Peer correction within an authentic language setting foster learning and the practice of the target language. Phillips (1993) notes that teachers should consider the number of students per group as it may bring about counterproductive results. He points out that a group of more than five will be challenging to control.

There are different kinds of strategies that teachers can adapt to deal with such problems. For example, teachers can tell students that they are in, Group A, Group B, and Group C, then they make them A's, B's, and C's to sit together. The other way of grouping is by the learners' month of birth. For example, January's together, February's together and so on.

Another possible solution is giving explanations and instructions that should be taken seriously. Giving Instruction Checking Questions (ICQ) is the most significant factor that teachers should consider. It is crucial to give a precise explanation at the very beginning of the game to shed a light on the purpose or why students are 'doing this'. Through clear instructions, students usually do not become confused and they are aware of their roles, the does and don'ts, which inadvertently increases their self-confidence.

Cameron (2001) also states that there are factors that are necessary for the teacher to follow besides knowledge and skill. Teachers should be encouraged to be more curious about their students' learning and thinking. More importantly, the teachers should find what makes learners interested and utilise them in the class. The teacher can use various ways such as mime, body movements and gestures to teach (Rixon, 1991).

\section{ThE SUITABILITY AND IMPLICATION OF GAMES}

Appropriateness is considered one of the most important factors for choosing a game. Games should be chosen carefully as they might not bring the desired results (Uberman, 1998). One factor which has a profound effect on choosing a game is the required time for completion. According to Piskozub (1994) games have limited time. Therefore, the teacher should decide on the amount of time spent on a task based on the student's level, the number of students and knowledge.

A game must be in correlation with students' age and level in which the class would reach its proper aims. Not all the games are suitable for students. Every student in a grade or level requires a specific subject, material, and type of game. For instance, games involving movements, competition and imitating are perfect for young age learners (Piskozub, 1994). Evaluating games can be useful when teachers want to choose a game.

As Piskozub (1995) notes, the age of a learner plays a very important role in the selection of games. Teachers should consider students' levels. Even, the most interesting and dynamic games cannot serve their purpose properly if the content of the new language goes beyond the level of students.

Hong (2002) states that if teachers want to have a proper choice of game for the lesson, they should take various factors into accounts such as the goal of a lesson, the focus of a language and the learners and technical factors.

Hong (2002) stated that a list of questions gives direction to games, including:

- Which language skill want to be introduced or practised based on the given name?

- Is the game in correlation with the students' age, skills, knowledge, and interest?

- Is it beneficial for the students?

- What are the positive results of using that game? 
- Do the teachers need to alter the game, or they can use it in its original form? If the teacher needs to alter that, is it difficult to implement?

- $\quad$ Are there adequate activities in the games so that students can participate and interact in the game?

These questions can highly decrease the chance of choosing an inappropriate game.

According to Halliwell (1992), games should ignite learners' imagination, involving their creativity, and not stifle their creativity. Therefore, games should bring fantasy. After a game has been chosen the implementation comes. According to Dobson (1997), many aspects should be considered when implementing a game in a foreign language. First, the instructor should have a full understanding of the game and its regulations. Moreover, the instructor should have a lesson plan to cover the sessions' direction. It is also important that the teacher make sure whether the game is entertaining or not and if not change it. Second, involvement is another crucial aspect that a teacher should consider. The game should make students more engaged and involved. Third, in the middle or end of the teaching, the instructor should play a game. That teacher should explain the rules at the beginning of the game. Forth, the teacher should control the discipline of a class during a game and use encouragement, when necessary. In fact, during a game, a class may become disorganised. Therefore, the teacher should use its authority to control them. During grouping, the teacher should group the students equally and not all the professionals with each other and fewer professionals with each other. Dobson (1997) mentions many experts hold the opinion that a teacher should make permanent groups. Lastly, when a game becomes boring the teacher should change it. He recommended never play a repetitive game for a long period because it makes students bored.

\section{Three Examples That CAN Be Used for TEACHING Vocabularies}

There has been an increase in the popularity of games in teaching vocabulary to young learners. Games give identity to students to have better confidence. To explore how the theory is translated into practise, I propose and discuss the three most common games in Iran.

The first game is called 'Back to the board'. This miming game is used to review vocabulary. In this game, the teacher divides the students into two teams and then one student from each team comes to the front of the class and sits opposite the board. The teacher should write three words on the board behind the players and the students should mime them. The teacher also should make sure that the words can be mimed. When the teacher says 'go', both teams start to mime the words for their players. The player who guesses the word correctly will get a point for the team.

The second game is called 'Bingo'. In this game, the instructor writes ten words on the board and every student chooses five words and writes them down. After that, the teacher chooses a word randomly without saying it and gives its definition or synonym to the students. If a student guessed the right word, he or she should shout bingo.

The third game is called 'Pictionary'. In this game, the class should be divided into two teams. Each team will sit on the opposite side of the classroom. A student from both teams will be asked to come to the board where the teacher will give out a word or phrase for students to be drawn on the board as a clue. The team who guesses the word will get the point.

The reason that I have chosen these games is their emphasis on teaching vocabularies through repetition and engagement, they become dominant in young learners' minds. Secondly, when I was an English teacher in Iran, the supervisor of the teaching school asked teachers to implement these games in the class and the main researcher has firsthand experience of implementing them in the classroom. The supervisor described these games in detail and emphasised the importance of these games are and how I should implement them. In the beginning, I as teachers did not believe in these kinds of games and I thought that would be a waste of time but as time went by teachers noticed how effective the games are and more importantly, students were fond of those games and asked us to implement it much more in the class.

\section{Discussion AND CONCLUSION}

The primary purpose of the current paper is to discuss the efficacy of games in teaching vocabulary to young learners. It is evident from the literature that games are influential in teaching vocabulary to young learners. It was discussed that games bring fun and energy to the class. By employing games students will be more energetic and delighted. Furthermore, games also boost their confidence and motivation to learn more efficiently. In classes with newcomer students who are not familiar with other classmates, games act as an ice breaker to get them more intimate with each other. Also, games highlight vocabularies so that students can learn faster and unconsciously while playing. Games create a relaxed and stress-free atmosphere for students in which enhances the educational outcome.

There are some notes for teachers as well. Even though games have substantiated that they are very influential in teaching vocabulary, they may still bring about some challenges for the teachers and the students.

Firstly, time management; teachers cannot control the time of the class during the games. One issue that many teachers face in playing games is time management. In other words, the teacher cannot find enough time to recap or practice at the very end of the game and the outcome may generate disappointing results.

Secondly, the atmosphere of the class; during the games students shout and move a lot so the class becomes uncontrollable. One of the noticeable issues is the atmosphere of the class that could be very chaotic and disorganised. 
Usually, during the games, children move a lot, and they also have lots of physical movements and more importantly, we hear lots of shouts and noises. To control these kinds of classes, the instructor should be fully aware of the students' personality traits to prepare the atmosphere for proper learning (Brown, 2001).

Thirdly, students' native language; usually during the games students only use their mother tongues and not English. Young learners tend to use their first language more than other languages. In this situation, the teacher should adopt a specific strategy and that strategy is responding in English although they speak in their mother language. Otherwise, the teacher could face a chaotic class.

Fourthly, anxiety and depression; playing games can make students a bit anxious because of the results. According to (Chuang, 2007) games can cause many harmful outcomes such as anxiety and depression. Chuang's (2007) study has proven that students' anxiety may increase as a result of being humiliated in front of other classmates.

Lastly, time fillers. Games are regarded as time fillers and teachers do not take them seriously. Silvers (1982) believes that many teachers are interested in using games as a teaching device. However, they often perceive them as time fillers. Silvers (1982) also mentions that many teachers ignore the fact that in a relaxing atmosphere real learning takes place. From my experience, I can say that in the English language institute that I used to teach in Iran most of the teachers were aliens to the games and they considered games as something worthless and distracting but gradually as time went by the supervisor held some meetings to get teachers more acquainted with the usage they have in teaching.

Game-based teaching approaches makes language learning more interesting and exciting (Soyoof, Jokar, Razavizadegan, \& Morovat, 2014). Teachers of young learners' should use their creativity and imagination to bring new and interesting games to the class so that the students will not get tired. Harmer (2001) states that young learners easily get tired and demotivated. Therefore, they cannot sit for a long period and do repetitive tasks. Besides, as mentioned earlier, the capacity of their attention is very low. Consequently, they easily get tired and because of that, the tasks should be very engaging and amusing.

Even though games have some challenges, limitation and teachers regard them as a time filler, this paper indicated that using educational games will enhance student's language learning. Games have challenges and issues; they are substantially influential, and their strengths outweigh their limitations. Games are proven to be effective, and more and more institutions are going toward employing games in their education.

It is recommended that instructors should use those kinds of methods that motivate students to involve and be more creative. By implementing vocabulary games students can learn the language much better. Game-based instruction has not been widely embraced by educators yet. They are used for a short period. Games are indeed helpful because by games teachers can create the context for students to use the language in a meaningful and useful way. Rohani and Pourgharib (2013) point out that by using games, the teacher can make a variety of contexts so that students can use the language for communication, exchanging information and expressing their opinions.

Learning vocabularies is the basis of students' level of comprehension (Nation, 2001; Radev, Hovy, \& McKeown, 2002). Teaching vocabularies through games to English young learners allow them to learn better and efficiently. Games have broad usages in education, not only in teaching vocabularies but also, in various disciplines and areas such as teaching grammar and listening. Therefore, more investigations should be conducted by scholars to get more acquainted with the games and their usages.

Instructors need to use new and modern strategies to boost students' vocabulary knowledge such as games, drama and computer-assisted language learning (Rohani \& Pourgharib, 2013). Games are indeed an influential and useful method rather than revision and presentation (Uberman, 1998). Due to the benefits that educational games have; they are used frequently. Games prepare the students to be responsible to be physically and mentally active. Games are student-oriented rather than teacher-oriented. In other words, the students' talking time will increase in comparison to the teacher talking time. The other factor is that games draw student's attention, make them more engaged, bring fun to the formal academic process and teach students to socialise. Furthermore, students can build up other skills such as turn-taking, working individually or with other team members to a specific aim.

Lastly, introduced games were a key factor in teaching vocabularies to young learners because games keep the children active all the time. As explained above, those three games are a few examples of games and teachers should bear in mind that games should be chosen appropriately.

\section{ACKNOWLEDGMENTS}

This study previously has been submitted as the author's assignment to Monash University.

\section{REFERENCES}

[1] Aghlara, L., \& Tamjid, N. H. (2011). The effect of digital games on Iranian children's vocabulary retention in foreign language acquisition. Procedia-social and Behavioural Sciences, 29, 552-560. https://doi.org/10.1016/j.sbspro.2011.11.275

[2] Ajibade, Y., \& Ndububa, K. (2008). Effects of word games, culturally relevant songs, and stories on students' motivation in a Nigerian English language class. TESL Canada Journal, 26(1), 27-48. https://doi.org/10.18806/tesl.v26i1.128

[3] Alavi, G. \& Gilakjani, A. P. (2019). The effectiveness of games in enhancing vocabulary learning among Iranian third grade high school students. Malaysian Journal of ELT Research, 16(1), 1-16. 
[4] Al-Masri, A. A., \& Najar, M. A. (2014). The effect of using word games on primary stage students' achievement in English language vocabulary in Jordan. American International Journal of Contemporary Research, 4(9), 144-152. Retrieved December 13, 2020, from https://bit.ly/3wBdoPv

[5] Allen, V. F. (1983). Techniques in teaching vocabulary. Oxford University Press: New York.

[6] Al Neyadi, O. (2007). The effects of using games to reinforce vocabulary learning. In Marifa H.C.T. (Ed.), Action research and initial teacher education in the UAE (pp. 99-107). HCT Press, UAE. Retrieved November 2020, from https://cutt.ly/BWiLL1b

[7] Anil, B. (2011). Teaching vocabulary through games- a sanguine step. i-Manager's Journal on English Language Teaching, 1(4), 46-50. https://doi.org/10.26634/jelt.1.4.1605

[8] Aslanabadi, H., \& Rasouli, G. (2013). The effect of games on improvement of Iranian EFL vocabulary knowledge in kindergartens. International Review of Social Sciences and Humanities, 6(1), 186-195.

[9] Bakhsh, S. A. (2016). Using games as a tool in teaching vocabulary to young learners. English language teaching, 9(7), 120128. http://dx.doi.org/10.55ow 39/elt.v9n7p120

[10] Blachowicz, C. L., \& Fisher, P. (2006). Teaching vocabulary in all classrooms. Columbus: OH: Prentice-Hall.

[11] Brown, H. D. (2001). Teaching by principle: An interactive approach to language pedagogy. New York: Longman.

[12] Cameron, L. (2001). Children learning a foreign language. In L. Cameron (Ed.). Teaching languages to young learners (pp 120). Cambridge: Cambridge University Press.

[13] Cárdenas, J., \& Ostrom, E. (2004). What do people bring into the game? Experiments in the field about cooperation in the commons. Agricultural Systems, 82(3), 307-326. https://doi.org/10.1016/j.agsy.2004.07.008

[14] Carter, R. (1998). Vocabulary: Applied linguistic perspectives (2nd edition). London, UK: Routledge.

[15] Chen, I. J. (2005). Using games to promote communicative skills in language learning. The Internet TESL Journal, 11(2), 1-4.

[16] Chuang, H. Y. (2007). The study of foreign language anxiety, English learning motivation and strategies in the elementary school. Unpublished master's thesis, National Chiayi University, Chiayi, Taiwan.

[17] Coady, J., \& Huckin, T. (1997). Second language vocabulary acquisition: a rationale for pedagogy. Cambridge: Cambridge University Press.

[18] Crystal, D. (2003). English as a global language (Second Edition). Cambridge: Cambridge University Press.

[19] Daneshfar, S., \& Moharami, M. (2018). Dynamic assessment in Vygotsky's sociocultural theory: Origins and main concepts. Journal of Language Teaching and Research, 9(3), 600-607. doi: http://dx.doi.org/10.17507/jltr.0903.20

[20] Decarrico, J. S. (2001). Vocabulary learning and teaching. In M. Celce-Murcia (Ed.), Teaching English as a second or foreign language (3rd Ed.) (p. 285-301). Boston: Heinle \& Heinle. Retrieved January 12, 2021, from https://cutt.ly/GWiZwdB

[21] Derakhshan, A., \& Khatir, E. D. (2015). The effects of using games on English vocabulary learning. Journal of Applied Linguistics and Language Research, 2(3), 39-47.

[22] Dolati, I., \& Mikaili, P. (2011). Opinion related to the main reasons on Iranian students' difficulties in spoken English proficiency. Australian Journal of Basic and Applied Sciences, 5(11), 1142-1148.

[23] Donaldson, M. (1978). Children's minds. London: Routledge.

[24] Donmus, V. (2010). The use of social networks in educational computer-game based foreign language learning. ProcediaSocial and Behavioural Sciences, 9(2000), 1497-1503. https://doi.org/10.1016/j.sbspro.2010.12.355

[25] Dobson, J. M. (1997). Effective techniques for English conversation groups. Washington: English Language Programs Division

[26] Dorshomal, N., Gorjian, B., \& Pazhakh, A. (2013). The role of pedagogical films in developing pre-intermediate Iranian EFL learners' speaking skill: The case of motivation. International Journal of Language Learning and Applied Linguistics World, 4(4), 254-268.

[27] Efendi, E. (2013). The use of games to improve vocabulary mastery. Journal de Physique III, 1(12), 78-84.

[28] Ekstam, J. M., \& Sarvandy, E. (2017). English language teaching in Iran: Tradition versus modernity. Chinese Journal of Applied Linguistics, 40(1), 112-119. https://doi.org/10.1515/cjal-2017-0007

[29] Erber, R., \& Markunas, S. (2006). Managing affective states. In J. P. Forgas (Ed.) Affect in Social Thinking and Behavior (pp. 253-266). Psychology Press: New York.

[30] Ersoz, A. (2007). Teaching English to young learners. Ankara: EDM Yayincilik.

[31] Ersoz, A. (2000). Six games for the EFL/ESL classroom. The Internet TESL Journal, 6(6)1-4. Retrieved October 17, 2020 , from http://iteslj.org/Lessons/Ersoz-Games.html

[32] Gairns, R., \& Redman, S. (1986). Working with words: A guide to teaching and learning vocabulary (pp. 74-80). Cambridge: Cambridge University Press.

[33] Ghasemi, A. A., \& Moharami, M. (2014). Gender, interestedness and learning durability. Instructional Technology, 55. https://itdl.org/Journal/Aug_14/Aug14.pdf\#page=59

[34] Haghighi, F. M. \& Norton, B. (2016). The role of English language institutes in Iran. TESOL Quarterly, 51(2), 428-438. https://doi.org/10.1002/tesq.338

[35] Halliwell, S. (1992). Teaching English in the primary classroom. New York: Longman.

[36] Hammer, J. (1991). The practice of English language teaching: New edition. New York: Longman.

[37] Hong, L. (2002). Using games in teaching English to young learners. The Internet TESL Journal. http://dx.doi.org/10.1073/pnas.0403723101

[38] Hughes, M. (1986). Children and number: Difficulties in learning mathematics. US: Wiley-Blackwell.

[39] Hung, H., Yang, J.C., Hwang, G., Chu, H., \& Wang, C. (2018). A scoping review of research on digital game-based language learning. Computers \& Education, 126, 89-104. doi:10.1016/j.compedu.2018.07.001

[40] Huyen, N. T. T., \& Nga, K. T. T. (2003). Learning vocabulary through games. Asian EFL Journal, 5(4), 90-105.

[41] Khan, T. (1998). Bringing up boys. London: Piccadilly Press

[42] Khosravi, R., Moharami, M., \& Karimkhanlouei, G. (2014). Perspectives and achievement of EFL students in teaching culture via two modes: Books vs. books plus films. Journal of Language Teaching and Research, 5(5), 1210-1217. doi:10.4304/jltr.5.5.1210-1217 
[43] Klopfer, E., Osterweil, S., \& Salen, K. (2009). Moving learning games forward: Obstacles, opportunities, \& openness. Boston: The Education Arcade.

[44] Kuo, Y. L. (2008). The effect of games in the fifth graders' English-speaking ability in an elementary school in Taipei County. Unpublished master's thesis, National Taipei University of Education, Taipei, Taiwan.

[45] Lee, W. R. (1979). Language teaching games and contests. Oxford: Oxford University Press.

[46] Lewis, G., \& Bedson, G. (1999). Games for children. New York: Oxford University Press.

[47] Maleki, H., Ghasemi, A. A., \& Moharami, M. (2015). CAVL: Does it develop learner's attitude?. Turkish Online Journal of Distance Education, 16(2), 122-136. https://dergipark.org.tr/en/download/article-file/156676

[48] Moharami, M. (2020): Adult English language learners in Iran. Monash University. Presentation. https://doi.org/10.26180/5f3b3c883ff53

[49] Naraghizadeh, M., \& Barimani, S. (2013). The effect of CALL on the vocabulary learning of Iranian EFL learners. Journal of Academic and Applied Studies, 3(8), 1-12. Retrieved October 18, 2020, from https://bit.ly/2OACqxi

[50] Nation, I. S. P. (2001). Learning vocabulary in another language. Cambridge University Press. Retrieved January 10, 2021, from https://cutt.ly/jWiLVNW

[51] Nguyen, T.H. \& Khuat, T.N. (2003). Learning vocabulary through games. Asian EFL Journal, 5(4), Retrieved January 1, 2021, from http://www.asian-efl-joumal.com/dec 03 vn.pdf

[52] Orlick, T. (2006). Cooperative games and sports: Joyful activities for everyone. Champaign, IL: Human Kinetics.

[53] Phillips, S. (1993). Young learners. Oxford: Oxford University Press.

[54] Piskozub, T. (1994). Vocabulary teaching games. Warsaw. WSIP.

[55] Piskozub, T. (1995). Play strategy in teaching young learners. In Per Bærentzen (Ed.). Aspekte der Sprachbeschreibung: Akten des (239-342). Linguistischen Kolloquiums, Aarhus.

[56] Radev, D. R., Hovy, E., \& McKeown, K. (2002). Introduction to the special issue on summarization. Computational linguistics, 28(4), 399-408. Retrieved October 7, 2020, from https://bit.ly/3cXm4YF

[57] Riahipour, P., \& Saba, Z. (2012). ESP vocabulary instruction: Investigating the effect of using a game-oriented teaching method for learners of English for nursing. Journal of Language Teaching \& Research, 3(6), 1258-1266. doi:10.4304/jltr.3.6.1258-1266.

[58] Richard-Amato, P. A. (1988). Making it happen: Interaction in the second language classroom: From theory to practice. New York: Longman.

[59] Rixon, S. (1991). How to use games in language teaching. London: Millan Publishers Ltd.

[60] Rogers, M., Miller, N., \& Hennigan, K. (1981). Cooperative games as an intervention to promote cross-racial acceptance. American educational research journal, 18(4), 513-516.

[61] Rohani, M., \& Pourgharib, B. (2013). The effect of games on learning vocabulary. International Research Journal of Applied and Basic Sciences, 4(11), 3540-3543. Retrieved October 10, 2020, from https://cutt.ly/MWiLNIN

[62] Sadeghi, K., \& Dousti, M. (2013). The effect of length of exposure to CALL technology on young Iranian EFL learners' grammar gain. English Language Teaching, 6(2), 14-26. Retrieved December 10, 2020, from https://bit.ly/3rYSQgv

[63] Sadeghi, K., \& Richards, J. C. (2015). Teaching spoken English in Iran's private language schools: Issues and options. English Teaching: Practice \& Critique, 14(2), 210-234. https://doi.org/10.1108/ETPC-03-2015-0019

[64] Soyoof, A., \& Jokar, M. (2014). Video game: A way to reduce inhibition and enhance language achievement. Procedia-Social and Behavioral Sciences, 98, 1850-1858. doi:10.1016/j.sbspro.2014.03.615

[65] Soyoof, A., Jokar, M., Razavizadegan, M. A., \& Morovat, E. (2014). The effects of learners' brain hemisphericity on their degree of vocabulary retention: A case study of Iranian high school students. Procedia-Social and Behavioral Sciences, 98, 1844-1849. doi:10.1016/j.sbspro.2014.03.614

[66] Silvers, S. M. (1982). Games for the classroom and the English-speaking club. English Teaching Forum, 20(2), 29-33.

[67] Slattery, M., \& Willis, J. (2001). English for primary teachers: A handbook of activities and classroom language (Vol. 1). Oxford: Oxford University Press.

[68] Stahl, S. (2005). Four problems with teaching word meanings. In E. H. Hiebert \& M. L. Kamil (Eds.), Teaching and learning vocabulary: Bringing research to practice (pp. 95-114). Mahwah, NJ: Erlbaum.

[69] Thornbury, S. (2006). How to teach vocabulary. Pearson Education: India.

[70] Uberman, A. (1998). The use of games for vocabulary presentation and revision. In English Teaching Forum 36(1), $20-27$. Retrieved December 9, 2020, from https://bit.ly/31YqMiN

[71] Ur, P. (1996). A course in language teaching. Cambridge: Cambridge University Press.

[72] Vernon, S. (2009). The benefits of using games. Retrieved October 20, 2020, from http://www.englishgames.com

[73] Vygotsky, L. S. (1962). Thought and language (E. Hanfmann \& G. Vakar, trans.). Cambridge, MA: The MIT Press.

[74] Wallace, M. J. (1982). Teaching vocabulary. London: Heinemann Educational Books Ltd. Cambridge University Press.

[75] Wright, A., Betteridge, D., \& Buckby, M. (2005). Games for language learning (3rd Ed.). New York: Cambridge University Press.

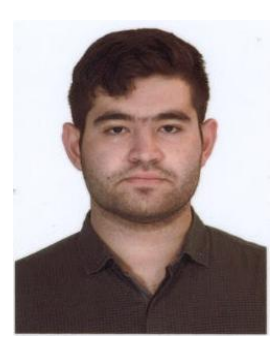

Amirhossein Naderiheshi is an MA candidate in TESOL at the Faculty of Education- Monash University. He has experience in teaching English at several language institutes in Tehran-Iran. He received many international certificates from Cambridge University. He also received a B.A in English Translation in 2018. His area of interest includes Teaching English to Speakers of Other Languages (TESOL), Curriculum and Teacher education. E-mail: Amir_naderi3473@yahoo.com 